\title{
Antidiarrhoeal Activity and Total Tannin Content of Ethanolic Leaf Extract of Codiaeum variegatum
}

\section{Zubair Khalid Labu, Farhina Rahman Laboni, Mir. Md. Abdullah-Al Mamun and Md. Sariful Islam Howlader}

\author{
Department of Pharmacy, World University of Bangladesh, Dhaka-1205, Bangladesh \\ Received: September 15, 2014; Accepted: May 20, 2015; Published (web): June 15, 2015

\begin{abstract}
The present study was designed to investigate the antidiarrhoeal activity and determine the total tannin content of the ethanolic extract of the leaves of Codiaeum variegatum (Family- Euphorbiaceae). The antidiarrhoeal activity was evaluated in castor oil-induced diarrhoea in mice and the total tannin content was determined by using the Folin-Coicalteu phenol reagent. The ethanolic extract of leaves of $C$. variegatum showed a positive effect on castor oil induced diarrhoea in mice. In the antidiarrhoeal assay the extract inhibited the mean number of defecation by $40.81 \%$ and $59.18 \%(\mathrm{p}<0.01 \& \mathrm{p}<0.001)$ at $250 \mathrm{mg} / \mathrm{kg}$ and $500 \mathrm{mg} / \mathrm{kg}$ body weight, respectively. The latent period for the extract treated group was $(\mathrm{p}<0.01 \& \mathrm{p}<0.001)$ increased as compared to control group. The total tannin content was quite significant and high in ethanolic extract ( $241.41 \mathrm{mg} / \mathrm{g}$ of tannic acid equivalent). Phytochemical screenings of the leaf extract indicated the presence of carbohydrate (reducing sugars), gums, steroids, alkaloids and tannins. Therefore, the results of the present study provide the scientific basis for the traditional uses of this plant as remedy for diarrhea.
\end{abstract}

Key words: Codiaeum variegatum, antidiarrhoeal, total tannin content, phytochemical screening

\section{INTRODUCTION}

Bangladesh possesses rich floristic wealth and diversified genetic resources of medicinal plants. The use of the plants, plant extracts and pure compounds isolated from natural sources provided the foundation for pharmacologically active compounds for drug discovery. C. variegatum belonging to the family Euphorbiaceae is one of the common medicinal plants grown in Indian subcontinent. Different parts of this plant have been used in traditional medicines.

C. variegatum, commonly known as Croton or Joseph's Coat, is one of the most popular ornamental plants because of vivid foliage colors and varied leaf shapes. C. variegatum is native to Indonesia, Malaysia, Philippines, India, Thailand and Sri Lanka. It is an evergreen shrub, up to $6 \mathrm{~m}$ in height but usually maintained at $60-90 \mathrm{~cm}$ and grows well in areas having humid climate. More than 200 varieties

Correspondence to: Zubair Khalid Labu E-mail:-zubair.labu@yahoo.com; Tel: +088-01558388956.

Dhaka Univ. J. Pharm. Sci. 14(1): 87-90, 2015 (June) of croton exist on the globe, available in different leaf sizes, shapes and color patterns. Young leaves are usually green, bronze, yellow, or red, later changes to gold, cream, white, scarlet, pink, maroon, purple, black or brown. Sometimes totally different forms of leaves and color variations occur on the same plant. Flowers are small, long, axillary, usually unisexual racemes. Fruits are globular capsules and 3-8 $\mathrm{mm}$ in diameter.

In addition to its esthetic value as an indoor plant, crotons are also well known for its medicinal value. The leaf extracts of crotons are reported to have many medicinal properties including purgative, sedative, antifungal, antiamoebic and anticancerous activities. ${ }^{1,2}$ The plant is also well reputed for the production of valuable secondary metabolites of alkaloids, terpenes and flavanoids in nature. ${ }^{3-5}$

\section{MATERIALS AND METHODS}

Collection and identification of plant material. The leaves of $C$. variegatum were collected from Khulna University, Khulna, Bangladesh. A specimen 
copy was deposited to Bangladesh National Herbarium for identification \& the accession number was DACB-34739.

Preparation of ethanolic extract. The collected plant part (leaves) was separated from undesirable materials and then were washed with water and airdried under shed followed by drying in an electric oven at $40{ }^{\circ} \mathrm{C}$. The dried leaves were ground into powder with the help of a suitable grinder (Capacitor start motor, Wuhu motor factory, China). The powder was stored in an airtight container and kept in a cool, dark and dry place. About $500 \mathrm{~g}$ of powered material was taken in a clean, flat-bottomed glass container and soaked in 1.5 litre of $80 \%$ ethanol. The container with its contents was sealed and kept for a period of 6 days accompanying occasional shaking and stirring. The whole mixture then underwent a coarse filtration by a piece of clean, white cotton material. Then it was filtered through Whatman filter paper (Bibby RE200, Sterilin Ltd., UK) and the filtrate was concentrated with rotary evaporator (Buchi, Switzerland) at a bath temperature not exceeding $40{ }^{\circ} \mathrm{C}$ to have gummy concentrate extract (yield approx. 6.2\%).

Test for different chemical groups. The freshly prepared crude extract was qualitatively tested for the presence of chemical constituents. For example, alkaloids were identified by the Dragendorff's reagent, flavonoids with the use of $\mathrm{Mg}$ and $\mathrm{HCl}$, tannins with ferric chloride and potassium dichromate solutions, and steroids with Liebermann-Burchard reagent. Reducing sugars with Benedict's reagent. ${ }^{6-8}$

\section{Test for antidiarrhoeal activity}

Test animals \& drugs. White albino mice (Swiss-wistar strain, body weight: 20-25 gm) of both sexes were used for in vivo antidiarrhoeal activity. They were housed in standard environmental conditions at animal house of Pharmacology Laboratory, BCSIR, Chittagong, Bangladesh. Animals were kept under standard environmental conditions (temperature: $\left(24.0 \pm 1.0{ }^{\circ} \mathrm{C}\right)$, relative humidity: 55-65\% and 12 hr light/12 hr dark cycle) and had free access to food and water. The cages were cleaned once daily. This study was carried out following approval from the ethical committee comprising pharmacologist and toxicologist expert on the use and care of animals of the BCSIR. Loperamide (Square Pharmaceuticals Ltd., Bangladesh) was used as standard drug for this study.

Chemicals. Folin- coicalteu phenol reagent and tannic acid were obtained from Sigma Chemical Co. (St. Louis, MO, USA). Tween 80 and sodium carbonate were of analytical grade and purchased from Merck (Darmstat, Germany).

Castor oil-induced diarrhoea. Antidiarrhoeal activity of leaf extract of $C$. variegatum was tested by using castor oil induced method in mice. ${ }^{9,10}$ Twenty swiss albino mice were randomly divided in to four groups $(n=5)$. Control group received only distilled water $2 \mathrm{ml} /$ mice, positive control group received loperamide $50 \mathrm{mg} / \mathrm{kg}$ body weight as standard and test groups received the extracts at the doses of 250 $\mathrm{mg}$ and $500 \mathrm{mg} / \mathrm{kg}$ body weight. Mice were housed in separate cages having paper placed below for collection of fecal matters. Diarrhea was induced in the mice by oral administration of castor oil (1.0 $\mathrm{ml} /$ mice). Extract and drugs were given orally 1 hour before the administration of castor oil. The time for first excretion of feces and the total number of fecal output by the animals were recorded. Normal stool was considered as numerical value 1 and watery stool as numerical value 2. Percent inhibition of defecation in mice was calculated by using the following equation: \% inhibition $=[(\mathrm{Mo}-\mathrm{M}) / \mathrm{Mo}] \times 100$; where, Mo $=$ Mean defecation of control and $\mathrm{M}=$ Mean defecation of test sample.

Total tannin content determination. The tannins were determined using the Folin- coicalteu phenol reagent as reported by Amorim. ${ }^{11}$ Briefly, 0.1 $\mathrm{ml}$ of the sample extract was added to $7.5 \mathrm{ml}$ of distilled water and $0.5 \mathrm{ml}$ of Folin-coicalteu phenol reagent, $1 \mathrm{ml}$ of $35 \%$ sodium carbonate solution and diluted to $10 \mathrm{ml}$ with distilled water. The mixture was shaken well, kept at room temperature for $30 \mathrm{~min}$ and absorbance was measured at $725 \mathrm{~nm}$ with a double beam Analykjena UV/Visible spectrophotometer 
(Model 205, Jena, Germany). Blank was prepared with water instead of the sample. A set of standard solutions of tannic acid is read against a blank. The results of tannins are expressed in terms of tannic acid in $\mathrm{mg} / \mathrm{g}$ of extract.

Total tannin content was determined as mg of tannic acid equivalent per gram using the equation obtained from a standard tannic acid calibration curve with intercept $(\mathrm{C})=-0.2583$, slope $(\mathrm{m})=4.5692$ and regression co-efficient $\mathrm{r}^{2}=0.9953$.

Statistical analysis. Data were presented as mean \pm standard error mean (SEM). Statistical analysis was carried out using one-way ANOVA followed by Dunnet's multiple comparisons. The results obtained were compared with the control group. $\mathrm{P}$ values $<0.05$ were considered to be statistically significant ( $p$ indicates probability).

\section{RESULTS AND DISCUSSION}

Chemical group test. Results of different chemical tests on the ethanolic extract of leaves of $C$. variegatum showed the presence of reducing sugar, tannins, steroid \& alkaloid (Table 1).

Table 1. Results of different group tests of ethanolic extract of leaves of $C$. variegatum.

\begin{tabular}{lc}
\hline Phytoconstituents & $\begin{array}{c}\text { Ethanol extract of } \\
\text { C. variegatum }\end{array}$ \\
\hline Alkaloid & + \\
Reducing sugars & + \\
Tannins & + \\
Gums & - \\
Flavonoids & - \\
Saponin & - \\
Steroid & + \\
\hline$(+):$ Positive result ;(-): Negative result &
\end{tabular}

Test for antidiarrhoeal activity. Table 2 showed the effect of the ethanolic extract of leaves of C. variegatum on castor oil-induced diarrhoeal method in mice. The result showed that the extract reduced the mean number of defecation which were $40.81 \%$ and $59.18 \%(\mathrm{P}<0.01 \& \mathrm{P}<0.001)$ at the doses of $250 \mathrm{mg} / \mathrm{kg}$ and $500 \mathrm{mg} / \mathrm{kg}$ respectively. The latent period for the extract treated group was $(\mathrm{P}<0.01$ \& $\mathrm{P}<0.001)$ increased as compared to control group.
Table 2. Antidiarrhoeal activity of the ethanolic extract of leaves of $C$. variegatum in castor oil induced diarrhoeal test method on mice.

\begin{tabular}{llccc}
\hline Sample & Dose & \multicolumn{2}{c}{ Mean \pm SE } & \begin{tabular}{c}
$\%$ \\
\cline { 3 - 4 }
\end{tabular} \\
\cline { 3 - 4 } & & $\begin{array}{c}\text { Latent } \\
\text { period }\end{array}$ & Defecation & \\
inhibition \\
Distilled & $2 \mathrm{ml} / \mathrm{mice}$, & $0.79 \pm$ & $9.8 \pm 0.86$ & -- \\
water & p.o. & 0.06 & & \\
Loperamide & $50 \mathrm{mg} / \mathrm{kg}$, & $2.21 \pm$ & $3.0 \pm 0.45^{* *}$ & 69.38 \\
& p.o. & $0.16^{* *}$ & & \\
Ethanol & $250 \mathrm{mg} / \mathrm{kg}$, & $1.05 \pm$ & $5.8 \pm 0.74^{*}$ & 40.81 \\
extract of $C$. & p.o. & $0.07^{*}$ & & \\
variegatum & $500 \mathrm{mg} / \mathrm{kg}$, & $1.56 \pm$ & $4.0 \pm 0.63^{* *}$ & 59.18 \\
& p.o. & $0.19^{* *}$ & & \\
\hline
\end{tabular}

Values are expressed as mean \pm SEM (Standard Error Mean); Et.: Ethanolic; * indicates $\mathrm{P}<0.01$; ** indicates $\mathrm{P}<0.001$, one-way ANOVA followed by Dunnet's test as compared to control; $\mathrm{n}=$ Number of mice; p.o.: per oral

Total tannin content. The total tannin content was calculated as quite high in ethanolic crude extract (251.41 mg/g of tannic acid equivalent) (Table 3).

Table 3. Total tannin content of ethanol extract of $C$. variegatum leaves.

\begin{tabular}{|c|c|c|}
\hline \multirow[t]{2}{*}{ Extract } & \multirow{2}{*}{$\begin{array}{l}\text { Avg. } \\
\text { absorbance } \\
\text { at } 725 \mathrm{~nm}\end{array}$} & Total tannin content \\
\hline & & $\begin{array}{l}\text { mg of tannic acid } \\
\text { equivalent (TAE) per } \\
\text { gm of dry extract }\end{array}$ \\
\hline $\begin{array}{l}\text { Ethanol extract of } \\
\text { C.variegatum leaves }\end{array}$ & $0.92 \pm 0.18$ & $241.41 \pm 0.82$ \\
\hline
\end{tabular}

Values are expressed as mean \pm SEM (Standard error mean).

Diarrhoea results from an imbalance between the absorptive and secretory mechanisms in the intestinal tract, accompanied by hurry, resulting in an excess loss of fluid in the faeces. In some diarrheas, the secretory component predominants, while other diarrhoeas are characterized by hypermotility. The use of castor oil induced diarrhoea model in our study is logical because the autacoids and prostaglandins are involved in producing diarrhoea in human. ${ }^{12,13}$ The liberation of ricinolic acid from castor oil results in irritation and imflammation of the intestinal mucosa, leading to release of prostaglandins, which stimulate motility and secretion. ${ }^{14}$ These observations suggest that those extracts at a dose of $250 \mathrm{mg} / \mathrm{kg}$ \& $500 \mathrm{mg} / \mathrm{kg}$ reduced diarrhoea by inhibiting castor oil induced intestinal accumulation of fluid.

Phytochemical screening revealed the presence of reducing sugar, tannin, steroid \& alkaloid. Earlier 
studies showed that anti-dysenteric and antidiarrhea properties of medicinal plants were due to tannins, alkaloids, saponins, flavonoids and sterols. ${ }^{15,16}$ Again, tannins and phenolics present in the plant extract are reported to inhibit release of autacoids and prostaglandins, thereby inhibit motility and secretion induced by castor oil. ${ }^{17}$

Hence, tannins, steroid \& alkaloid may be responsible for anti-diarrhoeal activity of $C$. variegatum leaves.

\section{CONCLUSION}

The present study demonstrates that the ethanol extract of $C$. variegatum leaves contains tannins and other pharmacologically active substance(s) possessing significant antidiarrhoeal activity. The present data provided a scientific support for the traditional use of this plant as diarrhoeal remedy. However, more detailed phytochemical analysis will be necessary to isolate and characterize the active compounds responsible for the antidiarrhoeal activities as well as to understand the exact mechanisms of action of these activities.

\section{REFERENCES}

1. Deshmukh, S.D. and Borle, M.N. 1975. Studies on the insecticidal properties of indigenous plant products. Ind. J. Ent. 37, 11-18.

2. Kupchan, S.M., Uchida, I., Branfman, A.R., Dailey, R.C. and Fei, B.Y. 1976. Antileukemic principles isolated from euphorbiaceae plants. Sci. 191, 571-572.

3. Puebla, P., Lopez, J.L., Guerrero, M., Carron, R., Martin, M.L., Roman, L.S. and Feliciano, A.S. 2003. Neo-clerodane diterpenoids from Croton schiedeanus. Phytochemistry 62, 551-554.

4. Maciel, A.M., Pinto, A.C., Brabo, S.N. and Silva, M.N. 1998. Terpenoids from Croton cajura. Phytochemistry 49, 823-826.

5. Martins, A.P., Salgueiro, L.R., Conclaves, M.J., Vila, R., Tomi, F., Adzet, T., Cunha, A.P., Canigueral, S. and Casanova, J. 2002. Antimicrobial activity and chemical composition of bark oil of Croton stellulifer. Planta Med. 66, 647-652.
6. Ghani, A. 1998. Medicinal Plants of Bangladesh, $1^{\text {st }}$ ed. Asiatic Society Dhaka, $1^{\text {st }}$ edition, p.13.

7. Evans, W.C. 1989. Trease and Evan's Textbook of Pharmacognosy. $13^{\text {th }}$ ed, Cambidge University Press, London, pp. 546-547.

8. Harborne, J.B., 1984. Phytochemal methods (A guide to modern techniques to plantanalysis). $3^{\text {rd }}$ ed. Chapman and Hall, London.

9. Shoba F.G. and Thomas M. 2001. Study of antidiarrheal activity of four medicinal plants in castor oil-induced diarrhea. J. Ethnopharmacol. 76, 73-76.

10. Hemayet, H., Musfizur, M.H., Ismet, A.J., Ishrat, N., Amirul, I. 2012. Antidiarrhoeal activity, nitric oxide scavenging and total tannin content from the bark of Ceriops decandra (Griff) Ding Hou. Int. J. Pharm. Sci. Res. 3, 1306-1311.

11. Amorim, E.L.C., Nascimento, J.E., Monteiro, J.M., Peixoto, S., Araujo, T.A.S. and Albuquerque, U.A.P. 2008. A simple and accurate procedure for the determination of tannin and flavonoid levels and some applications in ethnobotany and ethnopharmacology. Funct. Ecosyst. Commun. 2, 88-94.

12. Horton, E.W., Main, I.H.M., Thampson, C.J. and Wright, P.M., 1968. Effect of orally administered, PCG on gastro secretion and gastrointestinal motility in man. Gut. 9, 291295.

13. Greenbargena, N.J., Arwanitakis, C., Hurwitz, A. and Azarnoff, D.L. 1978. In drug development of gastrointestinal disorders, (eds.), Chirchill Livingston, New York, pp. 155156.

14. Pierce, N.F., Carpenter, C.C.J., Elliot, H.Z. and Greenough, W.B. 1971. Effect of protaglandins, theohylline and Cholera exotoxine upon transmucosal water and electrolyte movement in canine jejunum. Gastroenterology 60, 22-32.

15. Galvez, J., Zarzuelo, A., Crespo, M.E., Lorento, M.D., Ocete, M.A. and Jimenez, J. 1993. Antidiarrhoeic activity of Euphorbia hirta extract and isolation of an active flavonoid constituent. Planta Med. 59, 333-336.

16. Loganga, O.A., Vercruysse, A. and Foriers, A. 2000. Contribution to the ethanobotanical, Phytochemical and pharmacology studies of traditionally used medicinal plant in the treatment of dysentery and diarrhoeal in Lomela area, Democratic Republic of Congo (DRC). J. Ethnopharmacol. 71, 411-423.

17. Veiga, Y.F., Zunino, L., Calixto, J.B., Pititucci, M.L. and Pinato, A.C. 2001. Phytochemical and antioedematogenic studies of commercial copaiba oils available in Brazil. Phytother. Res. 15, 476-480. 